\title{
Kelimpahan dan Keanekaragaman Bakteri Pada pembenihan Ikan Lele (Clarias gariepinus) dengan Sistem Air Tertutup (Close Water System)
}

\section{Abundance and Diversity of Bacteria on Catfish Nursery Rearing (Clarias gariepinus) With Closed Water System (Close Water System)}

\author{
Muhammad Hanif Azhar ${ }^{1)^{*}}$, Mohammad Faizal Ulkhaq ${ }^{1)}$, Suciyono ${ }^{1)}$, Prayogo ${ }^{2)}$. \\ ${ }^{I}$ Program studi Budidaya Perairan, Fakultas Kelautan dan Perikanan, PSDKU Universitas \\ Airlangga di Banyuwangi \\ ${ }^{2}$ Departemen Manajemen Kesehatan Ikan dan Budidaya Perairan, Fakultas Perikanan dan \\ Kelautan, Universitas Airlangga \\ *Email.hanifazhar@fpk.unair.aci.id
}

\begin{abstract}
Abstrak
Penelitian ini bertujuan untuk mengidentifikasi jenis bakteri yang terdapat pada kolam pembenihan ikan lele (Clarias gariepinus) dengan menggunakan sistem air tertutup (Close water system). Data yang diambil meliputi kelimpahan dan keanekaragaman bakteri pada air dan pencernaan benih, pertumbuhan ikan serta parameter kualitas air. Wadah penelitian berupa 3 kolam beton berukuran 3 $\mathrm{x} 1 \mathrm{x} 0,8 \mathrm{~m}^{3}$ dengan jumlah benih tebar 3000 ekor/ kolam. Hasil yang diperoleh menunjukkan bahwa kelimpahan bakteri tertinggi pada permukaan dan dasar kolam adalah pada kolam $\mathrm{C}$ dengan jumlah

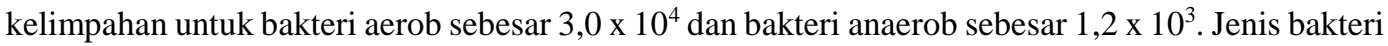
yang dominan ditemukan pada perairan dan saluran pencernaan adalah dari genus Bacillus, Clostridium dan Lactobacillus. Kualitas air masih dalam kisaran normal dengan suhu berkisar antara 28 - $30{ }^{\circ} \mathrm{C}, \mathrm{pH}(6,0-7,0)$, DO (4,5 - 5,7 ppm), ammonia (0,06-0,03 ppm), nitrit (0 ppm) dan nitrat (0 - $5 \mathrm{ppm})$.
\end{abstract}

Kata Kunci : Jenis bakteri, Ikan lele (Clarias gariepinus), Sistem air tertutup

\section{Abstract}

This research aimed to identify types of bacteria existed in nursery rearing pond of catfish (Clarias gariepinus) using closed water system. The observed data include bacterial abundance and diversity in the water and in the fish digestion system, fish growth and water quality. This research was performed in the media of 3 concrete pools with the size of $3 \times 1 \times 0.8 \mathrm{~m} 3$ containing fish stock spreading of 3000 tail / pond. The obtained results showed that the highest abundance of bacteria was found in the surface and the bottom of pond $C$ with the abundance number of $3,0 \times 10^{4}$ and 1,2 $\mathrm{x} 10^{3}$ for aerobic and anaerobic bacteria, respectively. Moreover, it was figured that the dominant bacterial species found in the water and the gastrointestinal tract were from the genus of Bacillus, Clostridium and Lactobacillus. Meanwhile, water quality in the pond was observed in the normal range with the temperatures of $28-30^{\circ} \mathrm{C}, \mathrm{pH}(6.0$ - 7.0), $\mathrm{DO}(4.5-5.7 \mathrm{ppm})$, ammonia (0.06 - 0.03 $\mathrm{ppm})$, nitrite $(0 \mathrm{ppm})$ and nitrate $(0-5 \mathrm{ppm})$.

Keywords: Type of bacteria, catfish (Clarias gariepinus), Closed water system.

\section{PENDAHULUAN}

Pembenihan merupakan faktor yang sangat penting dalam menunjang kegiatan budidaya. Kebutuhan benih ikan yang sehat dan sesuai dengan standar mutlak dibutuhkan karena menjamin keberhasilan dalam kegiatan budidaya. Ikan lele (Clarias sp.) merupakan salah satu jenis komoditas yang banyak dikonsumsi 
oleh masyarakat di Indonesia. Berdasarkan data statistik yang diperoleh dari KKP 2015, nilai produksi perikanan budidaya dari jenis ikan lele meningkat sebesar 29,48\% dari 543. 774 ton pada tahun 2013 menjadi 679.379 ton pada tahun 2014. Dengan semakin meningkatnya jumlah produksi maka berpengaruh juga terhadap kebutuhan benih ikan lele.

Penerapan teknologi juga dilakukan dalam kegiatan pembenihan ikan lele. Salah satunya adalah dengan menggunakan padat tebar tinggi tanpa menggunakan pergantian air (Close Water System). Keuntungan yang didapat dari pembenihan dengan sistem ini yaitu tingginya hasil panen benih yang diperoleh dalam waktu yang sama dibandingkan dengan sistem tradisional. Sedangkan kelemahan dari sistem pembenihan ini adalah banyaknya buangan limbah organik pada kolam pembenihan akibat sisa pakan yang tidak termakan serta kotoran dari benih ikan lele yang bisa menjadi masalah pada kegiatan pembenihan. Salah satu efek dari akumulasi limbah organik ke dalam kolam pembenihan adalah dapat menyebabkan ikan lele menjadi stress dan mudah terserang penyakit. Adapun penyakit yang sering menyerang pada kegiatan pembenihan adalah dari golongan bakteri. Kandungan bahan organik yang sangat tinggi pada kolam pembenihan ikan lele dapat menyebabkan tumbuhnya banyak jenis bakteri baik yang bersifat menguntungkan maupun yang merugikan.

Pendekatan mengenai jenis keanekaragaman mikroorganisme berperan penting dalam kegiatan pembenihan ikan lele, serta untuk mengetahui potensi kandidat bakteri menguntungkan yang dapat dimanfaatkan pada kegiatan pembenihan ikan lele. Maka informasi mengenai keanekaragaman bakteri pada kolam pembenihan ikan lele dengan sistem tanpa pergantian air akan menjadi informasi yang sangat penting dalam upaya pengembangan di bidang mikrobiologi akuakultur.

\section{METODOLOGI PENELITIAN}

\section{Pengambilan Sampel}

Sampel air diperoleh dari kolam pembenihan ikan lele dumbo 
menggunakan sistem air tertutup (Close water System). Pengambilan sampel dilakukan pada 3 kolam berbeda (A,B, dan C). Perlakuan yang diberikan adalah berupa titik pengambilan sampel yaitu 1) permukaan air, tengah dan dasar kolam. Pengambilan sampel dilakukan dengan mengambil air pada permukaan, tengah dan dasar kolam dengan menggunakan botol film.

\section{Isolasi dan Identifikasi Bakteri}

Isolat bakteri diisolasi dan ditumbuhkan pada media Nutrient Agar (NA) kemudian diinkubasi selama 24 jam pada suhu $28{ }^{\circ} \mathrm{C}$. Selanjutnya dilakukan karakterisasi berdasarkan morfologi koloni, pewarnaan Gram dan uji biokimia (uji OF, motilitas, oksidase, dan katalase). Hasil pengamatan yang diperoleh lalu dicocokkan dengan kunci identifikasi berdasarkan tabel Cowan (Cowan and Steel, 1993).

\section{Parameter Kualitas Air}

\section{Parameter kualitas air yang} diukur antara lain suhu, $\mathrm{pH}, \mathrm{DO}$, ammonia, nitrit, dan nitrat. Pengukuran kualitas air yang dilakukan setiap hari antara lain suhu, pH dan DO setiap pagi dan sore hari.
Sedangkan untuk pengukuran kualitas air mingguan antara lain berupa ammonia, nitrit dan nitrat.

\section{Pertumbuhan Ikan}

Pemeliharaan benih ikan dilakukan selama 30 hari pada 3 kolam dengan ukuran $3 \times 1 \times 0,8 \mathrm{~m}^{3}$ dengan jumlah total benih yang ditebar adalah 3000 ekor. Panjang rata-rata saat awal tebar adalah 3,00 $\mathrm{cm}$ dengan berat rata-rata 0,24 gram. Sampling benih dilakukan setiap 7 hari sekali. Parameter pertumbuhan yang diamati antara lain panjang dan berat ikan pada semua kolam.

\section{ANALISA DATA}

Analisis data dilakukan dengan menggunakan analisis deskriptif. Parameter yang di analisis berupa kelimpahan bakteri, isolasi dan identifikasi bakteri serta parameter kualitas air.

\section{HASIL DAN PEMBAHASAN}

Hasil untuk kepadatan dari bakteri pada setiap kolam pembenihan ikan lele dapat dilihat pada tabel 1 . 
Tabel 1. Kelimpahan Bakteri pada kolam pembenihan ikan lele dumbo (Clarias gariepinus)

\begin{tabular}{ccc}
\hline \multirow{2}{*}{ Kolam } & \multicolumn{2}{c}{ Kepadatan } \\
\cline { 2 - 3 } & Aerob & Anaerob \\
\hline $\mathrm{A}$ & $2,9 \times 10^{3}$ & $6,0 \times 10^{2}$ \\
$\mathrm{~B}$ & $2,5 \times 10^{3}$ & $9,4 \times 10^{2}$ \\
$\mathrm{C}$ & $3,0 \times 10^{4}$ & $1,2 \times 10^{3}$ \\
\hline
\end{tabular}

Dari Hasil penghitungan

kepadatan bakteri pada setiap kolam budidaya ikan lele diketahui bahwa pada kolam C memiliki kepadatan tertinggi diantara kolam lainnya baik untuk penghitungan bakteri jenis aerob $\left(3,0 \times 10^{4}\right)$ maupun anaerob $\left(1,2 \times 10^{3}\right)$. Tingginya jumlah bakteri aerob dibandingkan dengan anaerob menandakan bahwa kondisi kolam masih memiliki tingkat oksigen yang cukup. Bakteri aerob baik dari jenis autotrofik maupun heterotrofik umumnya lebih dominan dalam proses penguraian bahan organik. Bakteri aerobik banyak ditemukan pada permukaan serta kolom perairan. Sedangkan untuk proses dekomposisi bahan organik yang terdapat pada dasar perairan pada umumnya didominasi oleh bakteri anaerobik maupun fakultatif (Fukuda, 2000). Hasil dari identifikasi bakteri yang diperoleh pada permukaan, kolom dan dasar kolam pembenihan ikan lele dapat dilihat pada tabel 2 .
Tabel 2. Jenis Bakteri pada permukaan, kolom dan dasar kolam pembenihan ikan lele dumbo (Clarias garipienus)

\begin{tabular}{|c|c|}
\hline Kolam & Jenis Bakteri \\
\hline A1 & Bacillus, Lactobacillus \\
\hline $\mathrm{A} 2$ & Clostridium \\
\hline A3 & Lactobacillus \\
\hline B1 & $\begin{array}{l}\text { Aeromonas, } \\
\text { Clostridium, } \\
\text { Lactobacilus }\end{array}$ \\
\hline B2 & $\begin{array}{l}\text { Bacillus, } \\
\text { Pediococcus, Staphylococcidium, }\end{array}$ \\
\hline B3 & $\begin{array}{l}\text { Bacillus, } \\
\text { Staphylococcus, }\end{array}$ \\
\hline $\mathrm{C} 1$ & $\begin{array}{l}\text { Aerococcus, Bacillus, } \\
\text { Escherchia, Staphylococcus, }\end{array}$ \\
\hline $\mathrm{C} 2$ & Clostridium \\
\hline $\mathrm{C} 3$ & $\begin{array}{l}\text { Aeromonas, } \quad \text { Clostridium, } \\
\text { Lactobacillus, Staphylococcus }\end{array}$ \\
\hline
\end{tabular}

Keterangan : 1) Permukaan; 2) Kolom; 3) Dasar kolam

Hasil identifikasi bakteri dari usus benih ikan lele dumbo pada akhir masa pemeliharaan dapat dilihat pada tabel 3.

Tabel 3. Jenis Bakteri pada usus Benih Ikan lele dumbo (Clarias garipienus)

\begin{tabular}{|c|c|}
\hline Kolam & Jenis Bakteri \\
\hline A & $\begin{array}{l}\text { Lactobacillus, Clostridum, Bacillus } \\
\text { Staphylococcus, Kurthia, }\end{array}$ \\
\hline B & $\begin{array}{l}\text { Clostridium, Bacillus } \\
\text { Staphylococcus, Kurthia, }\end{array}$ \\
\hline $\mathrm{C}$ & Clostridium, Bacillus \\
\hline
\end{tabular}

Berdasarkan dari hasil identifikasi, secara umum diperoleh bakteri yang dominan dan ditemukan pada setiap kolam budidaya antara lain adalah dari genus Bacillus, Clostridium dan Lactobacillus yang ditemukan pada bagian permukaan, kolom dan dasar perairan. Sedang untuk bakteri dari genus E.coli 
ditemukan pada kolam B dan C serta dari bagian permukaan kolam.

Hasil dari identifikasi bakteri pada kolam budidaya diperoleh bakteri yang dominan yaitu dari genus Bacillus, Clostridium dan Lactobacillus. Genus Bacillus dan Clostridium ditemukan pada semua kolom perairan. Sedangkan untuk genus Lactobacillus ditemukan pada permukaan dan dasar dari perairan.

Bacillus merupakan genus bakteri heterotrof yang dapat melakukan proses nitrifikasi dan denitirifikasi. Ebeling et al. (2006), menyatakan bakteri heterotrof dari genus Bacillus memiliki produksi biomassa 40 kali lebih besar dibanding dengan bakteri autotrof dalam proses nitrifikasi. Pertumbuhan bakteri heterotrof dipengaruhi oleh 3 hal yaitu : 1) proses asimilasi nitrogen menjadi sel, 2) diasimilasi nitrogen dari hasil proses respirasi serta 3) denitrifikasi nitrit dan nitrat (Woon, 2007).

Clostridium adalah genus bakteri gram positif, bersifat heterotrof, anaerobik serta membentuk endospora. Genus Clostridium banyak ditemukan pada lingkungan anaerobik seperti lumpur dan limbah (White, 1995). Peranan utama dari Clostridium di alam adalah untuk proses degradasi bahan organik menjadi alkohol, $\mathrm{CO}_{2}, \mathrm{H}_{2}$, mineral dan asam (Hippe et al., 1992).

Lactobacillus merupakan bakteri garam positif, heterotrof dan fakultatif anaerob. Lactobacillus masuk ke dalam kelompok bakteri asam laktat karena mampu mengubah laktosa atau gula lainnya menjadi asam laktat. Uji tantang dengan menggunakan

Lactobacillus rhamnosus mampu menurunkan tingkat mortalitas pada ikan rainbow trout yang terinfeksi Aeromonas salmonicida (Nikoskelainen, 2001).

Hasil pengukuran parameter kualitas air yang dilakukan pada kolam budidaya ikan lele antara lain suhu, DO, nitrit, nitrat dan ammonia dapat dilihat pada tabel 4 .

Tabel 4. Kisaran Parameter Kualitas Air pada Kolam Budidaya Ikan Lele

\begin{tabular}{cccccc}
\hline Kolam & $\begin{array}{c}\text { Suhu } \\
\left({ }^{\mathbf{}} \mathbf{C}\right)\end{array}$ & $\begin{array}{c}\text { DO } \\
(\mathbf{m g} / \mathbf{l})\end{array}$ & $\begin{array}{c}\text { Nitrit } \\
(\mathbf{m g} / \mathbf{l})\end{array}$ & $\begin{array}{c}\text { Nitrat } \\
(\mathbf{m g} / \mathbf{l})\end{array}$ & $\begin{array}{c}\text { Ammonia } \\
(\mathbf{m g} / \mathbf{l})\end{array}$ \\
\hline $\mathrm{A}$ & $28-30(29)$ & $4,5-5,5(5,0)$ & 0 & $0-5(5)$ & $0,25-0,5(0,38)$ \\
$\mathrm{B}$ & $28-30(29)$ & $4,6-5,7(5,2)$ & 0 & $0-5(5)$ & $0,50-0,7(0,63)$ \\
$\mathrm{C}$ & $28-30(29)$ & $4,5-5,5(5,0)$ & 0 & $0-5(5)$ & $0,25-0,5(0,38)$ \\
\hline
\end{tabular}


Berdasarkan dari hasil pengukuran parameter kualitas air bahwasanya parameter kualitas air pada kolam budidaya ikan lele masih dalam kondisi normal untuk kegiatan pembeniha ikan lele dumbo. Suhu memiliki pengaruh terhadap proses fisika, kimia dan biologi pada badan air (Effendi, 2000). Setiap spesies ikan memiliki kisaran suhu optimal yang berbeda. Hasil dari pengukuran suhu air kolam budidaya adalah berkisar pada suhu $29{ }^{\circ}$ C. Suhu tersebut masih dalam kisaran optimal dalam budidaya ikan lele. Suhu optimal bagi pertumbuhan ikan lele yaitu berkisar antara $25-32{ }^{\circ} \mathrm{C}$ (Boyd dan Lichtkoppler 1979).

Kandungan oksigen pada semua kolam masih dalam tahap normal untuk kegiatan budidaya ikan lele yaitu dengan rata-rata $5 \mathrm{mg} / 1$. Oksigen merupakan senyawa terpenting dalam perairan baik untuk makro maupun mikroorganisme. Oksigen terlarut pada peraiaran akan dimanfaatkan oleh mikroorganisme khususnya bakteri dalam proses dekomposisi bahan organik serta mineralisasi senyawa organik menjadi anorganik yang terlarut dalam perairan berupa nutrient seperti nitrat dan phosphat (Nagata et al., 2003). Apabila ketersediaan oksigen pada perairan menurun, maka akan mengakibatkan penurunan kualitas air pada perairan dan kehidupan pada perairan akan terganggu (Prihadi, 2005).

Nitrat merupakan hasil akhir dari proses nitrifikasi oleh bakteri Nitrobacter. Nitrat relatif bersifat tidak toksik bagi organisme peraiarn. Nitrat digunakan sebagai penanda eutrofikasi pada perairan. Hasil dari pengukuran pada air kolam diketahui pada setiap kolam memiliki nilai konsetrasi berkisar $5 \mathrm{mg} / \mathrm{l}$. Hal ini dapat disebabkan oleh tingginya padat tebar ikan sehingga berpengaruh terhadap kandungan bahan organik pada kolam budidaya. Tingginya kandungan nitrat pada sutu perairan akan dapat menyebabkan eutrofikasi yang selanjutnya dapat menstimulir pertumbuhan algae secara pesat (Effendi, 2000).

Ammonia merupakan produk akhir pada proses penguraian protein.. Berdasarkan hasil dari pengukuran ammonia pada air kolam diketahui nilai konsentrasinnya adalah 0,38 $0,63 \mathrm{mg} / 1$. Nilai ammonia tersebut sangat tinggi dan dapat 
mempengaruhi kondisi ikan lele yang dipelihara. Tingginya ammonia pada kolam dipengaruhi juga oleh tingkat kepadatan ikan. Ammonia pada lingkungan budidaya ikan lele berasal dari sisa pakan yang tidak termakan serta hasil ekskresi berupa feses. Selain itu ammonia juga berasal dari proses dekomposisi bahan organik (Duborow et al., 1997). Menurut Boyd (1982), konsentrasi ammonia sebesar $0,52 \mathrm{mg} / 1$ dapat menurunkan pertumbuhan ikan dari channel catfish sebesar $50 \%$ dan pada konsentrasi sebsesar 0,97 ppm menyebabkan ikan tidak dapat tumbuh.

\section{KESIMPULAN}

Berdasarkan dari hasil penelitian diperoleh Kepadatan tertinggi terdapat pada kolam C dengan nilai kepadatan 3,0 x $10^{4}$ pada kondisi aerob dan $1,2 \times 10^{3}$ pada kondisi anaerob. Dominansi bakteri dari kolam pembenihan dan saluran pencernaaan benih ikan lele dumbo berasal dari genus Bacillus, Clostridium dan Lactobacillus. Kualitas air pada kolam budidaya pembesaran masih dalam kondisi optimal antara lain suhu $\left(29{ }^{\circ} \mathrm{C}\right)$, kandungan oksigen terlarut (5,0 - 5,2 $\mathrm{mg} / 1)$, nitrit $(0 \mathrm{mg} / 1)$, nitrat $(5 \mathrm{mg} / \mathrm{l})$ serta ammonia $(0,38-0,63 \mathrm{mg} / 1)$.

\section{DAFTAR PUSTAKA}

Boyd CE, Lichtkoppler. 1979. Water Quality Management in Pond Fish Culture. International Center For Aquaclture. Agriculture Experimental Station. USA.

Boyd, C. E. 1982. ter Quality Management in Pond Fish Culture. Elsevier Scientific Publishing Company. Amsterdam-oxford. New York. Duborow RM, Crosby DM, Brunson MW. 1997. Ammonia in Fish Pond. Southern Regional Aquaculture Center. SRAC Publ. No. 463.

Ebeling, J.M., Timmons, M.B., Bisogni, J.J. 2006. Engineering analysis of stoichiometry of photoautotrophic, autotrophic and heterotrophic removal of ammonia-nitrogen aquaculture Aquaculture 257, 346-358

Effendi, H. 2000. Telaah Kualitas Air : Bagi Pengelolaan Sumberdaya dan Lingkungan Perairan. Fakultas Perikanan dan Ilmu Kelautan. IPB. 259 Hal.

Fukuda R. 2000. Microbial Degradation of Proteinaceous Organic Matter in Marine Environments, University of Tokyo. Tokyo.Japan.

Hippe H, Anderseen JR, Gottschalk G. 1992. The genus Clostridium non-medical. Di dalam Balows A, Truper HG, Dwarkin M, Harden W, Schleifer K-H, The prokaryot. A Handbook in The Biology of Bacteria : 
Ecophysology, isolation, identification, Application. Vol II. Edisi ke-2. New York : Springer-Verlag.

Kelautan dan Perikanan. 2015. Kelautan dan Perikanan dalam Angka tahun 2015. Pusat Data, Statistik dan Informasi. Kementerian Kelautan dan Perikanan.

Nikoskelainen S, Ouwehand AC and Bylund G. 2003. Immune enhancement in rainbow trout (Oncorhynchus mykiss) by potential probiotic bacteria (Lactobacillus rhamnosus). Fish \& Shellfish Immunology IS : 443-452.

Nagata T, Meoq B, Kirchman DL. 2003. Microbial Degradation of Dissolved Organic Matter in Sea Water, Journal of Limnology and Oceanography 48, 745-754.

Nikoskelainen S, Ouwehand AC, Salminen $\mathrm{S} \&$ Bylund $\mathrm{G}$ (2001a). Protection of rainbow trout (Oncorhynchus mykiss) fromfurunculosis byLactobacillus

rhamnosus.Aquaculture 198:2 $29-236$

Prihadi, T.H. 2005. Pengelolaan Budidaya Ikan Secara Lestari di Waduk (Studi Kasus di Perairan Waduk Cirata, Jawa Barat). [Disertasi]. Bogor : Sekolah Pascasarjana, Institut Pertanian bogor.

White, D. 1995. The Physiology and biochemistry of Prokaryot. New york. Oxford Univ Pr.

Woon BH. 2007. Removal of nitrat nitrogen in conventional wastewater treatment plants. Skripsi. Faculty of Civil

Engineering. University Teknologi Malaysia

Cowan and Steel. 1993. Manual for Microbiology Identification of Medical Bacteria. Edition III. Cambridge University Press. New York. Cambridge. Hal 4245.

Jumiarni, D. 2012. Isolasi dan Identifikasi Bakteri Sedimen Waduk. Jurnal Exacta 8(1): 111.

Sudarmono, PP. 2016. Mikrobioma: Pemahaman Baru tentang Peran Mikroorganisme dalam Kehidupan Manusia. Editorial Mikrobioma 4(2): 71-75. 
